\title{
Sistem Produksi dan Potensi Ekonomi Peternakan Kambing Lokal Bligon di Desa Girimulyo, Kecamatan Panggang, Gunungkidul
}

\author{
R. Widiati*, T. A. Kusumastuti \\ Fakultas Peternakan, Universitas Gadjah Mada
}

\begin{abstract}
ABSTRAK
Penelitian bertujuan untuk menentukan potensi ekonomi dan faktor-faktor yang mempengaruhi pendapatan peternakan Kambing lokal Bligon pada masyarakat Desa Girimulyo, Kecamatan Panggang Gunungkidul. Data dikumpulkan dari 30 peternak kambing Bligon yang diambil secara purposive sebagai responden. Pengambilan data dengan wawancara langsung secara mendalam kepada responden menggunakan bantuan kuesioner. Analisis enterprise budgeting digunakan untuk menganalisis potensi ekonomi dalam bentuk pendapatan bersih dan return to labor and farm management pada sistem produksi kambing Bligon yang dilakukan peternak. Selanjutnya untuk menentukan faktor-faktor yang mempengaruhi pendapatan peternak menggunakan analisis regresi berganda. Hasil penelitian menunjukkan bahwa peternakan kambing Bligon dengan pemeliharaan rata-rata 2 betina produktif dan 1 ekor jantan penggemukan dapat memberikan pendapatan bersih sebesar Rp 936.463,- atau dalam bentuk return to labor and management sebesar Rp 2.380.241,-/peternak/tahun. Faktor-faktor yang berpengaruh signifikan positif terhadap pendapatan peternak adalah jumlah pemilikan kambing $(\mathrm{P}<0,05)$ dan jumlah anak per kelahiran $(\mathrm{P}<0,01)$, sedangkan mortalitas anak berpengaruh negative $(\mathrm{P}<0,01)$. Peternakan kambing Bligon merupakan alternatif potensial yang dapat dikembangkan untuk menghasilkan pendapatan bagi masyarakat pedesaan. Namun, merupakan tantangan bagi para ilmuwan untuk mengembangkan teknologi produksi kambing yang terkait dengan perbaikan interval kelahiran, jumlah anak dan mortalitas.
\end{abstract}

Kata kunci: Enterprise budgeting, Gunungkidul, Peternakan kambing Bligon, Return to labor and management

\section{Production System and Economic Potential of the Bligon Local Goat Farming in Girimulyo Village, Panggang Sub District of Gunungkidul}

\begin{abstract}
This study was aimed to determine the economic potential and factors that influenced to the income of the Bligon local goat farming in Girimulyo Village, Panggang sub District of Gunungkidul. Data was collected from 30 Bligon goat farmers in the study area which taken purposively as the respondents. Data were collected by direct in-depth interviews to the respondents using questionnaires. Both quantitative and qualitative data were analysed. Enterprise Budgeting was made to analyze the economic potential of Bligon goat farming in the form of net farm income and return to labor and management on the production system that farmers doing. Furthermore, to determine the factors that influence the income of farmers using multiple regression analysis. The results showed that the Bligon goat farming with average maintenance of 2 heads of productive females and 1 head fattening male can give net farm income of Rp 936,463 or in the form of return to labor and management amounting to $R p$ 2,380,241/ farmer/year. Factors that significantly positive have affect to the farmer income were number of goat ownership $(P<0.05)$ and litter size $(P<0.01)$, while mortality have negative effect $(P<0.5)$. The Bligon goat farming was a potential alternative that can developed to generate income for rural communities. However, it is a challenge for scientists to develop technologies that support the improvement of production aspects associated with kidding interval, litter size and mortality.
\end{abstract}

Keywords: Bligon goat farming, Enterprise budgeting, Gunungkidul, Return to labor and managemen

\section{PENDAHULUAN}

Indonesia adalah negara agraris karena sekitar $85 \%$ penduduknya tinggal di pedesaan dan berprofesi sebagai petani. Meski demikian, rata-rata kepemilikan lahan garapan sempit, sekitar $0,1-0,5$ ha terutama di Pulau Jawa (BPS, 2013) Petani kecil umumnya berpenghasilan rendah sehingga untuk meningkatkan pendapatan umumnya mereka memelihara ternak, seperti kambing meskipun hanya sebagai pelengkap dan penunjang dalam sistem pertanian. Murjito, et al. (2011) menyatakan bahwa hampir semua kambing di Indonesia dipelihara oleh petani kecil di pedesaan dalam skala kecil sekitar 2-7 ekor karena mereka hanya

*Penulis Korespondensi: R. Widiati

Alamat: Jalan Fauna No. 3, Bulaksumur, Sleman, Yogyakarta

E-mail: rini_w@ugm.ac.id memiliki modal kecil. Lebih lanjut dikatakan bahwa sumber daya petani kecil terbatas dan terkendala secara bervariasi seperti kondisi pertanian, ketersediaan air dan kesuburan tanah, luas lahan serta jenis tanaman dan ternak (Verschelde et al., 2013). Namun demikian diyakini bahwa ternak yang dipelihara oleh petani kecil dapat digunakan untuk mengurangi kemiskinan, terutama di negara-negara miskin dan sedang berkembang (Pica-Ciamarra et al., 2015). Kambing adalah ruminansia kecil sehingga pemeliharaannya tidak membutuhkan sumber daya dan modal besar dibanding sapi. Kambing tumbuh lebih cepat daripada sapi dan sebagai penghasil daging merah seperti daging sapi. Dengan demikian pengembangan usaha peternakan kambing akan mendukung pemenuhan konsumsi daging merah masyarakat Indonesia 
sekaligus memberikan kesempatan kerja bagi masyarakat pedesaaan.

Maart-Noelck dan Musshoff (2013) menyatakan bahwa dalam hal penggunaan investasi atau modal untuk memperluas usaha tani, petani memiliki kecenderungan untuk mempelajari investasi sebelumnya dan menilai dari apa yang diperoleh dari waktu ke waktu. Mereka akan memutuskan untuk berinvestasi jika investasinya terbukti menguntungkan. Namun, untuk melakukannya, petani-petani kecil perlu memahami karakteristik sistem produksi untuk mengembangkan usaha yang menguntungkan.

Dalam membuat rencana bisnis pertanian diperlukan analisis, antara lain enterprise budgeting adalah suatu teknik akuntansi yang digunakan untuk menangani masalah skala ekonomi, penggunaan input atau faktor produksi, perubahan teknologi dan inflasi serta tingkat bunga dalam penggunaan modal. Alat analisis tersebut akan membantu petani dalam membuat keputusan yang paling tepat dalam mengembangkan rencana bisnis untuk menghasilkan keuntungan mereka (Bradford dan Debertin, 1985; Kay et al., 2008; Paudel et al., 2013).

Pada tahun 2015, jumlah populasi kambing di Indonesia adalah 18.879.596 ekor, sedangkan di Provinsi Yoyakarta adalah 411.209 ekor. Kenaikan tingkat populasi kambing nasional pada periode 20102015 adalah rata-rata 1,29\%/tahun. Pada periode yang sama, Provinsi Daerah Istimewa Yogyakarta memiliki tingkat pertumbuhan populasi kambing yang lebih tinggi daripada tingkat nasional yaitu rata-rata 4,68\%/tahun (Ditjen PKH, 2016). Kambing Bligon merupakan salah satu jenis kambing lokal yang banyak dipelihara oleh masyarakat pedesaan Yogyakarta, khususnya di Kabupaten GunungKidul (Murdjito dkk., 2011). Kambing Bligon merupakan keturunan kambing Ettawa dengan kambing Kacang, namun persentase darah kambing kacang lebih dari 50\%.

Selanjutnya berdasarkan hasil penelitian mereka menunjukkan bahwa sebanyak $37,9 \%$ peternak kambing Bligon menyatakan tujuan beternak adalah sebagai sumber pendapatan, sedangkan 34,5\% adalah untuk tabungan dan $27,6 \%$ bertujuan memproduksi pupuk untuk mendukung usaha tanaman pertanian. Ini menunjukkan bahwa Yogyakarta memiliki potensi untuk pengembangan peternakan kambing Bligon. Tujuan dari penelitian ini adalah untuk menentukan potensi ekonomi dan faktor-faktor yang mempengaruhi pendapatan pada usaha peternakan Kambing Bligon di Desa Girimulyo, Kecamatan Panggang Gunungkidul, Yogyakarta.

\section{MATERI DAN METODE}

\section{Lokasi Penelitian}

Lokasi penelitian diambil secara purposive di Desa Girimulyo, kecamatan Panggang Gunungkidul. Jenis kambing Bligon banyak dipelihara di pantai utara Jawa seperti Cirebon, Semarang dan daerah Gunungkidul, dimana desa Girimulyo Kabupaten
Gunungkidul adalah merupakan asal usul pengembangbiakan kambing Bligon tersebut (Anonimus, 2009 dan Murdjito et al., 2011). Oleh karena itu penelitian dilakukan di Desa Girimulyo.

\section{Pengumpulan Data}

Data dikumpulkan dari 30 responden peternak kambing Bligon di wilayah penelitian yang diambil secara purposive. Dasar pemilihan responden untuk mengeksplorasi data parameter produksi adalah minimum kepemilikan satu ekor kambing betina produktif dan sudah dipelihara minimal 1 tahun, dengan pertimbangan lama pengalaman tersebut akan dapat diidentifikasi data parameter teknis dan ekonomi. Data dikumpulkan dengan metode survei melalui wawancara mendalam kepada responden dengan menggunakan kuesioner terstruktur sesuai dengan tujuan penelitian.

Data identitas peternak dan parameter teknis, seperti interval kelahiran, mortalitas, jumlah anak per kelahiran/litter size, pemberian pakan dan cara mengelola ternak dikumpulkan pada bulan Juli sampai September 2013 dengan asumsi bahwa data terkait teknologi belum berubah. Sementara data ekonomi berupa harga input dan output disesuaikan dan diambil pada bulan Desember 2015.

\section{Analisis Data}

Data hasil isian kuesioner yang telah lengkap kemudian ditabulasi dan diedit, selanjutnya menjadi dasar untuk analisis lebih lanjut. Analisis dilakukan secara deskriptif untuk menetapkan karakteristik demografi dan sistem produksi ternak, serta analisis Enterprise Budgeting untuk menentukan potensi ekonomi usaha peternakan Kambing Bligon. Paudel et al. (2013) dan Kay et al.(2008), menyatakan bahwa Enterprise Budgeting (EB) adalah salah satu alat analisis yang dapat digunakan untuk menggali pendapatan usaha pertanian atau peternakan sebagai dasar untuk mengembangkan rencana bisnis yang lebih menguntungkan di masa depan. Analisis pendapatan dalam EB adalah sebagai berikut :

Pendapatan bersh $/$ net income $=\mathrm{TR}-\mathrm{TC}$

$\mathrm{TR}=$ Total penerimaan dari hasil peternakan kambing Bligon (Rp/peternak/tahun)

$\mathrm{TC}=\mathrm{FC}+\mathrm{VC}$

Dimana, $\mathrm{FC}=$ Fixed cost $(\mathrm{Rp} /$ peternak/tahun $)$ $\mathrm{VC}=$ Variable cost(Rp.peternak/tahun)

Return to labor and management $=$ Net Income + Opportunity cost of family labor

Selanjutnya analisis kuantitatif regresi berganda digunakan untuk menentukan faktor-faktor yang berpengaruh terhadap pendapatan peternak kambing Bligon. Memon et al. (2015) juga telah menerapkan model regresi berganda untuk menentukan hubungan fisik antara input dan output pada produksi ayam petelur. Dalam penelitian ini model regresi berganda dalam bentuk sebagai berikut :

$\mathrm{Y}=\mathrm{f}(\mathrm{X} 1 \mathrm{X} 2 \mathrm{X} 3 \mathrm{X} 4 \mathrm{X} 5 \mathrm{X} 6, €)$ 
$\mathrm{Y}$ adalah variabel tergantung dan $\mathrm{X}$ adalah variabel bebas

Dimana :

$\mathrm{Y}=$ Output berupa pendapatan usaha kambing Bligon dalam bentuk return to labor and management (Rp/tahun/peternak)

$\mathrm{X}_{1}=$ umur (tahun)

$\mathrm{X}_{2}=$ pendidikan (umur)

$\mathrm{X}_{3}=$ pengalaman beternak (tahun)

$\mathrm{X}_{4}=$ jumlah kambing (ekor)

$\mathrm{X}_{5}=$ luas lahan pertanian $\left(\mathrm{m}^{2}\right)$

$\mathrm{X}_{6}=$ interval kelahiran (bulan)

$\mathrm{X}_{7}=$ jumlah anak per kelahiran (ekor)

$\mathrm{X}_{8}=$ mortalitas $(\%)$

$€=$ Error term.

\section{HASIL DAN PEMBAHASAN}

\section{Identitas Responden}

Tabel 1 menunjukkan bahwa jumlah pemeliharaan kambing rata-rata sekitar 6 ekor terdiri dari 2 ekor induk, 1 ekor jantan dewasa dan sisanya anak dan kambing muda. Ini menunjukkan bahwa skala usaha kambing Bligon adalah kecil sehingga pendapatan sedikit atau kecil. Rata-rata kepemilikan lahan pertanian adalah $0,56 \mathrm{ha} /$ petani. Ini cukup luas dibandingkan dengan lahan petani di daerah irigasi terutama di Jawa yang hanya sekitar 0,10 ha (Widiati, 2006).

Lokasi penelitian merupakan daerah kering pegunungan kapur sehingga rata-rata kepemilikan lahan lebih luas, namun produktivitas lahan untuk tanaman pangan yang tumbuh seperti padi, jagung dan singkong adalah rendah. Pada umumnya daun tanaman kayu-kayuan seperti sengon, gliriside, dan turi, serta rumput lapangan yang tumbuh di sekitar lokasi penelitian dimanfaatkan sebagai sumber pakan kambing.

\section{Sistem Produksi Kambing Bligon}

Tabel 1 menunjukkan bahwa $90 \%$ peternak responden mempunyai mata pencaharian sebagai petani dan peternak kambing. Dapat dikatakan secara umum, petani di lokasi penelitian memelihara kambing terintegrasi dengan tanaman pertanian. Sesuai dengan Moraes et al.(2014) yang menyatakan bahwa banyak wilayah di dunia menghadapi kerawanan pangan, oleh karena itu produksi pertanian-peternakan diproyeksikan akan meningkat di masa yang akan datang. Manfaat usaha peternakan yang terintegrasi dengan pertanian adalah: 1) perbaikan dalam proses produksi dan lingkungan pertanian, termasuk perbaikan dalam penyerapan angkatan kerja, stabilitas faktor ekonomi dan pengurangan risiko, dan 2) ketahanan pangan yang lebih besar untuk memenuhi kebutuhan konsumen (FAO, 2010 dalam Moraes et al., 2014).

Peternak responden adalah peternak skala kecil yang umumnya hanya memanfaatkan sisa hasil pertanian yang tidak bisa digunakan sebagai bahan pangan manusia, seperti daun-daunan dan rumput. Disisi lain, kambing menghasilkan pupuk kandang yang dimanfaatkan sebagai pupuk untuk menyuburkan lahan pertaniannya. Meskipun peternak kecil, mereka juga memanfaatkan teknologi seperti penggunaan pakan penguat terutama untuk penggemukan kambing dan menanam rumput unggul serta tanaman legume di sekitar lahan pertaniannya.

Nugent dan Yotopoulus (1976) menyatakan teknologi bisa meningkatkan produksi dan produktivitas, namun demikian teknologi membutuhkan modal, sementara umumnya petani hanya memiliki modal terbatas untuk mengakses teknologi. Oleh karena itu, pengembangan usaha kambing pada petani kecil membutuhkan bantuan finansial kredit murah agar dapat mengakses teknologi yang dapat meningkatkan produktivitas, serta meningkatkan skala usahanya. Berikut kondisi system produksi ternak kambing Bligon dari responden.

Pakan ternak. Biaya pakan mengambil persentase tertinggi $(60-70 \%)$ dari semua biaya operasional (Murdjito et al., 2011). Oleh karena itu biaya pakan merupakan kunci bagi keuntungan peternak. Jenis pakan kambing di lokasi penelitian antara lain berupa rumput budidaya, rumput lapangan, daun singkong dan tanaman legume antara lain berupa kaliandara, lamtoro dan turi yang ditanam dari lahan mereka sendiri, sehingga mereka tidak mengeluarkan uang tunai untuk pemenuhan pakan hijauan, namun

Tabel 1. Identitas peternak kambing Bligon sebagai responden di tempat penelitian $(n=30)$

\begin{tabular}{clcc}
\hline \hline No. & \multicolumn{1}{c}{ Item } & Rata-rata & Standar deviasi \\
\hline 1. & Umur peternak (tahun) & 43,53 & 5,37 \\
2. & Pendidikan formal (tahun) & 9,33 & 2,62 \\
3. & Pengalaman memelihara kambing (tahun) & 18,40 & 5,50 \\
4. & Kepemilikan kambing (ekor) & 5,93 & 2,26 \\
& cempe (ekor) & 1,23 & \\
& Kambing muda (ekor) & 1,67 & \\
& Kambing jantan (ekor) & 1 & 2410 \\
& Kambing betina (ekor) & 2,03 & \\
6. & Luas lahan pertanian (m $\left.{ }^{2}\right)$ & 5613 & \\
& Mata pencaharian (Jumlah responden/\%) & & \\
& Petani dan peternak kambing & $27(90)$ & \\
& Pekerjaan luar usahatani & $1(3,33)$ & $2(6,67)$ \\
\hline
\end{tabular}


Tabel 2. Enterprise budgeting untuk peternakan kambing Bligon (Rp/farm/tahun)

\begin{tabular}{|c|c|c|}
\hline Item & $\begin{array}{c}\text { Rata-rata } \\
\text { parameter teknis dan ekonomi }\end{array}$ & $\begin{array}{c}\text { Rata-rata } \\
\text { (Rp/Peternak/tahun) }\end{array}$ \\
\hline \multicolumn{3}{|l|}{ Penerimaan } \\
\hline $\begin{array}{l}\text { Penjualan cempe dari } 2 \text { induk } \\
\text { kambing }\end{array}$ & $\begin{array}{l}\text { Interval kelahiran rata-rata } 8,83 \text {, litter } \\
\text { size: } 1,56 \text {, harga anak } 7 \text { bulan }=\mathrm{Rp} \\
1.200 .000 \text {, mortalitas anak sampai umur } \\
7 \text { bulan sebesar } 11,12 \%\end{array}$ & $2.641 .815,-$ \\
\hline Hasil dari pemeliharaan 1 ekor & Rata-rata harga kambing penggemukan & \\
\hline $\begin{array}{l}\text { kambing jantan penggemukan } \\
\text { Pupuk kandang } \\
\text { Total penerimaan (A) }\end{array}$ & $=\operatorname{Rp} \quad 1.750 .000,-$ & $\begin{array}{l}557.334,- \\
306.222,- \\
3.505 .371,-\end{array}$ \\
\hline \multicolumn{3}{|l|}{ Biaya } \\
\hline $\begin{array}{l}\text { Bunga modal untuk membeli } 2 \\
\text { kambing betina dan } 1 \text { kambing } \\
\text { jantan }\end{array}$ & $\begin{array}{l}\text { Rata-rata harga kambing induk }=\mathrm{Rp} \\
1.180 .000 \text {, kambing jantan umur } 7 \text { bulan } \\
=- \text { Rp } 1.200 .000,00 \\
\text { Tingkat bunga modal } 6 \% / \text { tahun }\end{array}$ & $213.600,-$ \\
\hline Depresiasi dari kandang kambing & $\begin{array}{l}\text { Harga pembuatan kandang }=\mathrm{Rp} \\
500.000,00 / \\
\mathrm{m}^{2} \text {, luas } 7,5 \mathrm{~m}^{2} \text { dengan umur teknis } 10 \\
\text { Tahun }\end{array}$ & $374.994,-$ \\
\hline $\begin{array}{l}\text { Total biaya tetap }(B) \\
\text { Biaya Variabel }\end{array}$ & & $588.594,-$ \\
\hline $\begin{array}{l}\text { Hijauan disamakan dengan } \\
\text { penggunaan tenaga kerja }=0,8 \text { jam } \mathrm{x} \\
365 \text { hari }(\mathbf{C})\end{array}$ & $\begin{array}{l}\text { Upah harian tenaga kerja }=\mathrm{Rp} 40.000 \\
\text { untuk bekerja } 8 \text { jam per hari }\end{array}$ & 1.443.778,- \\
\hline Konsentrat $=0,43 \mathrm{~kg} \times 365$ hari & $\begin{array}{l}\text { Rata-rata harga konsentrat }=\mathrm{Rp} 2600 / \\
\mathrm{kg}\end{array}$ & $408.536,-$ \\
\hline Peralatan & 1 unit/tahun & $81.000,-$ \\
\hline Obat-obatan & Diluar subsidi & $47.000,-$ \\
\hline Total biaya variable (D) & & $1.980 .314,-$ \\
\hline Total biaya $(\mathbf{E})=\mathbf{B}+\mathbf{D}$ & & $2.568 .908,-$ \\
\hline $\begin{array}{l}\text { Estimasi pendapatan bersih }(\mathbf{F})=\mathbf{A}- \\
\mathbf{E}\end{array}$ & & 936.463,- \\
\hline $\begin{array}{l}\text { Estimasi pendapatan (return to labor } \\
\text { and management) }(\mathbf{G})=\mathbf{F}+\mathbf{C}\end{array}$ & & 2.380.241,-- \\
\hline
\end{tabular}

membutuhkan waktu dari sebagian pekerjaan keluarga untuk mengumpulkan pakan ternak. Biaya pakan dalam bentuk tunai dikeluarkan untuk membeli pakan penguat seperti dedak dan atau pollard. Rata-rata pakan penguat yang diberikan pada kambing Bligon di daerah penelitian adalah $0,430 \mathrm{~kg} /$ hari/peternak untuk pemeliharaan rata-rata 5 ekor. Jumlah tersebut termasuk rendah, karena seharusnya kebutuhan pakan kambing Bligon sebesar 3\% dari berat badan berdasarkan bahan kering (BK) (Nuraini, 2014). Berdasarkan perhitungan lebih lanjut, apabila berat badan induk kambing Bligon sekitar $25 \mathrm{~kg}$, dengan perbandingan pemberian pakan hijauan dan konsentrat $75 \%: 25 \%$, maka dibutuhkan pakan penguat sekitar $0,234 \mathrm{~kg} / \mathrm{ekor} / \mathrm{hari}$. Menurut Murdjito dkk. (2011) ; Ginting dan Simon, (2009), pada kambing yang sedang dalam masa pertumbuhan dan kambing jantan yang digemukkan paling tidak dibutuhkan pakan penguat \pm $1 \mathrm{~kg} /$ hari/ekor, tergantung berat kambing. Dengan demikian pemberian pakan penguat rata-rata pada peternak responden sangat kecil atau kemungkinan dipenuhi hanya dengan pakan hijauan yang tidak membeli. Hal ini menunjukkan bahwa modal peternak sangat terbatas, sehingga hanya mampu membayar sedikit untuk pakan penguat, tergantung pada ketersediaan uang harian di tangan (Widiati, 2006; Murdjito et al., 2011).

Perkembangbiakan ternak. Produk utama peternakan kambing adalah cempe yang lahir untuk dibesarkan sampai dewasa dan kemudian dijual untuk memperoleh pendapatan, dengan demikian kualitas reproduksi kambing betina harus dikelola dengan baik. Umumnya pengembangbiakan kambing dilakukan dengan kawin alami menggunakan jantan unggul yang ada di lokasi penelitian dan sekitarnya. Parameter teknis dari reproduksi ternak akan mempengaruhi biaya dan pendapatan seperti $(\mathrm{S} / \mathrm{C})$, interval kelahiran, litter size atau jumlah anak per kelahiran dan kematian anak. Hasil penelitian menunjukkan bahwa parameter teknis rata-rata $\mathrm{S} / \mathrm{C}$ adalah $1,44 \mathrm{kali}$, interval kelahiran $(\mathrm{CI})$ 8,83 bulan, litter size 1,56 ekor dan mortalitas anak sampai umur 7 bulan adalah $11,12 \%$ (Tabel 2). 
Tabel 3. Hasil analisis regresi faktor-faktor yang berpengaruh terhadap pendapatan peternak

\begin{tabular}{lccc}
\hline \hline \multicolumn{1}{c}{ Parameter } & Koefisien regresi & t & Signifikansi \\
\hline Konstanta & $-187238,87$ & $-0,06$ & 0,95 \\
$\mathrm{X}_{1}$ (umur) & $-58274,95$ & $-0,73$ & 0,48 \\
$\mathrm{X}_{2}$ (pendidikan) & $-91695,01$ & $-1,12$ & 0,28 \\
$\mathrm{X}_{3}$ (pengalaman) & 53251,91 & 0,76 & 0,46 \\
$\mathrm{X}_{4}$ (jumlah kambing) & 411895,11 & 2,63 & 0,02 \\
& & & 0,59 \\
$\mathrm{X}_{5}$ (Luas lahan pertn.) & $-75,34$ & & 0,86 \\
$\mathrm{X}_{6}$ (Interval kelahiran) & $-49250,45$ & $-0,54$ & 0,00 \\
$\mathrm{X}_{7}$ (litter size) & 1497000,00 & $-0,17$ & 0,00 \\
$\mathrm{X}_{8}$ (mortalitas) & $-53472,49$ & 4,46 & \\
$\mathrm{R}^{2}=0,69$ & & $-5,14$ & \\
Adjusted $\mathrm{R}^{2}=0,57$ & & & \\
$\mathrm{~F}$ hit $=5,88$, Sig $<0,001$ & & & \\
\hline
\end{tabular}

Sementara itu, penelitian yang sama di desa yang berbeda menunjukkan bahwa hasil parameter tersebut masing-masing $\mathrm{S} / \mathrm{C}=1,23 \mathrm{kali}, \mathrm{CI}=8,53$ bulan dan litter size 1,74 ekor, namun tidak ada data tentang kematian anak (Murdjito et al., 2011). Hasil penelitian Aka (2008), menunjukkan bahwa mortalitas anak kambing Ettawa pada peternakan rakyat rata-rata adalah $7,15 \%$.

Pemasaran produk kambing. Hasil penelitian menunjukkan bahwa peternak kambing biasanya menjual kambing pada umur 7-12 bulan kepada tengkulak desa. Penjualan langsung di pasar dianggap banyak memakan waktu dan biaya transport mahal karena penjualan kambing hanya berkisar 1-2 ekor per peternak dan hanya pada waktu-waktu tertentu. Mereka mengatakan bahwa waktu untuk menjual kambing di pasar dianggap membuang waktu karena waktu lebih baik digunakan untuk bekerja di ladang.

\section{Analisis Enterprise Budgeting Kambing Bligon}

Parameter teknis dan ekonomis dalam sistem produksi kambing Bligon digunakan sebagai dasar analisis EB. Secara umum dapat dikatakan bahwa peternakan kambing Bligon dapat dijadikan sebagai bisnis komersial, dan untuk itu semua biaya dan penerimaan harus diperhitungkan untuk mendapatkan keuntungan. Hasil observasi lapangan menunjukkan bahwa penggunaan pakan ternak kambing yang berupa hijauan tidak pernah membeli, oleh karena itu biaya dinilai berdasarkan penggunaan tenaga kerja yang dialokasikan untuk merumput. Dalam sistem produksi kambing, petani pada umumnya menghasilkan anak untuk dipertahankan sampai sekitar 1 tahun dan kemudian dijual sebagai penerimaan atau pendapatan kotor peternak. Namun, beberapa petani menyimpan hewan sebagai tabungan dalam arti bahwa mereka akan menjual kapan saja pada saat mereka membutuhkan uang tunai.

Enterprise budgeting peternakan kambing Bligon pada responden ditunjukkan pada Tabel 2. Dari Tabel 2 menunjukkan bahwa dengan parameter teknis S/C 1,44 kali, interval kelahiran $8,83 \propto 9$ bulan, litter size 1,56 ekor dan mortalitas anak sampai umur 7 bulan adalah $11,12 \%$ menghasilkan pendapatan bersih (net farm income) sebesar Rp 936.46,/peternak/tahun. Jika dihitung berdasarkan pendapatan yang berasal dari hasil tenaga keluarga dan manajemen (return tolabor and management) adalah sebesar Rp,-2.380.241,--

Pendapatan kambing Bligon tersebut dapat ditingkatkan apabila parameter teknis dapat diperbaiki dari kondisi saat ini. Bagi petani, ternak kambing sebagai tabungan yang dapat dijual sewaktu-waktu jika mereka membutuhkan uang tunai, maka dapat dikatakan bahwa pendapatan tersebut bermanfaat bagi petani untuk menunjang kehidupan mereka. Di daerah pedesaan dimana tidak ada kesempatan kerja lain, maka peternakan dianggap kegiatan yang tetap dalam kehidupan mereka, sehingga walaupun nilai marjinal tenaga kerja rendah namun menunjukkan manfaat yang positif. Sesuai dengan hasil penelitian Widiati, (2012) pada usahatani sapi potong, meskipun pendapatan kecil namun usahatani tersebut tetap keberadaannya.

Dalam kegiatan budidaya pertanian, minimnya kebijakan pemerintah atau kurang tepatnya dengan kondisi petani maka akan menghasilkan nilai pendapatan rendah, khususnya terkait dengan biaya input yang harus dibayar secara tunai oleh petani (Stür et al., 2013). Berdasarkan EB untuk peternakan kambing Bligon, beberapa aspek yang bisa diperbaiki untuk meningkatkan pendapatan adalah: memperkecil $\mathrm{S} / \mathrm{C}$ dibawah 1,44 , memperpendek interval kelahiran di bawah 8,83 bulan dan mengurangi angka kematian anak di bawah $11,12 \%$. Selain itu, kebijakan pemerintah sangat mendesak diperlukan untuk memberikan kredit murah dengan tingkat bunga rendah di bawah 6 .

\section{Faktor-Faktor yang Berpengaruh Terhadap Pendapatan Peternak}

Hasil analisis regresi terkait dengan faktor-faktor yang berpengaruh terhadap pendapatan peternak ditunjukkan seperti Tabel 3.

Secara matematis persamaan regresi adalah sebagaiberikut: 


$$
\begin{aligned}
\mathrm{Y}= & -187239-58274,95 \mathrm{X}_{1}-91695,01 \mathrm{X}_{2}+53251,91 \mathrm{X}_{3} \\
& +411895,11 \mathrm{X}_{4}-75,34 \mathrm{X}_{5}-49250,45 \mathrm{X}_{6}+ \\
& 1497000,00 \mathrm{X}_{7}-53472,49 \mathrm{X}_{8}
\end{aligned}
$$

Tabel 3 menunjukkan bahwa variabel $\mathrm{X}_{1}$ sampai dengan $\mathrm{X}_{7}$ secara bersama-sama berpengaruh signifikan terhadap pendapatan (return to family labor and management), dengan $\mathrm{P}<0,01$ dan Adjusted $\mathrm{R}^{2}=$ 0,574 , yang berarti $57,40 \%$ variabel $\mathrm{X}_{1}$ sampai dengan $\mathrm{X}_{7}$ secara bersama-sama berpengaruh signifikan terhadap pendapatan peternak kambing Bligon. Namun demikian secara parsial yang berpengaruh secara signifikan positif terhadap pendapatan adalah $\mathrm{X}_{4}$ (jumlah kambing, $\mathrm{P}<0,05$ ), $\mathrm{X}_{7}$ (litter size, $\mathrm{P}<0,01$ ), dan $\mathrm{X}_{8} \quad$ (mortalitas, $\quad \mathrm{P}<0,01$ ) berpengaruh signifikan negative sebesar koefisien regresinya. Berdasarkan hasil persamaan regresi, dapat dijelaskan bahwa kenaikan jumlah pemilikan kambing satu ekor akan dapat menambah pendapatan (return to family labor and management) sebesar Rp 411.895,-. Selanjutnya kenaikan jumlah litter size 1 ekor akan meningkatkan pendapatan sebesar Rp 1.497.000,-. Sedangkan kenaikan mortalitas $1 \%$ akan menurunkan pendapatan peternak sebesar Rp 53.472,-Berdasarkan hasil penelitian ini maka untuk meningkatkan pendapatan peternak kambing dapat dilakukan dengan meningkatkan skala usaha, disertai dengan meningkatkan jumlah anak per kelahiran (littersize) dan menekan mortalitas.

\section{KESIMPULAN}

Peternakan kambing Bligon merupakan alternatif usaha yang dapat menghasilkan pendapatan untuk dikembangkan pada masyarakat pedesaan. Meskipun pendapatan usaha tani kambing Bligon kecil, namun dalam praktek pertanian tetap bertahan, ini menunjukkan adanya kelangkaan kesempatan kerja di daerah pedesaan. Pendapatan usaha tani kambing Bligon dapat ditingkatkan dengan memperbaiki parameter reproduksi terutama litter size dan mortalitas anak. Disamping itu, peternak perlu meningkatkan skala usaha disertai dengan kebijakan pemerintah untuk memberikan pinjaman dengan tingkat bunga rendah dibawah 6\% dan adopsi teknologi pada sistem produksi kambing Bligon guna memperbaiki parameter reproduksi induk yang lebih baik dibanding kondisi saat ini.

\section{DAFTAR PUSTAKA}

Aka, R. 2008. Doe productivity and kid crop of etawah grade does kept under individual and group housing in Turi Sub District, Sleman District-DIY Province. Mediagro 4 (2): 25-31.

Anonimus. 2009. Jenis ternak Kambing yang ada di Indonesia. Available athttps://www.google.co.id/?gws rd=cr\&ei=G09 oWdDQKMTdvgTPvaOQCA\#q=asal+usul+kam bing+Bligon. Diakses pada 14 Juli 2017.
Bradford, G.L. \& D.L. Debertin. 1985. Establishing linkages between economic theory and enterprise budgeting for teaching and extension programs. Southern Journal of Agricultural Economics 17(02): 67-76.

BPS. 2013. Sensus pertanian di Indonesia (angka sementara). Siaran pers statistik No. 62/09/ XVI, Sept. 2013.

Ditjen PKH. 2016. Statistik Peternakan dan Kesehatan Hewan. Kementrian Pertanian Republik Indonesia. Jakarta.

Ginting and P. Simon. 2009. Technical Guidelines for Management of Feeding Goat in the Business. Centerfor Research and Development of Animal Husbandry Agency for Agricultural Research and Development. Bogor

Kay, R.D., W.M. Edwards \& P.A. Duffy. 2008. Farm Management. Sixth Edition. McGraw-Hill Companies Inc. 1221 Avenue, New York.

Maart-Noelck, S.C. and O. Musshoff. 2013. Investing Today or Tomorrow? An Experimental Approach to Farmers'Decision Behaviour. Journal of Agricultural Economics 64 (2): 295-318.

Memon, M.I.N., S. Noonari, M. Asif, M. Pathan, R. Jamali, Z. Memon, D. khan, S.A. Sial. 2015. Economic analysis of poultry egg production in Quetta District Balochistan Pakistan. J. of Marketing and Consumer Research 14: 5-12.

Moraes, A., P.C.F. Carvalho, S.B.C. Lustosa, C.R. Lang dan L. Deiss. 2014. Research on integrated crop-livestock systems in Brazil. Revista Ciência Agronômica 45 (5): 1024-1031.

Murdjito, G., I.G.S. Budisatria, Panjono, N. Ngadiyono \& E. Baliarti. 2011. Performances of Bligon goats kept byfarmers at Girisekar village, Panggang, Gunungkidul. Bulletin of Animal Science, 35 (2): 86-90.

Nugent, J.B. and P.A. Yotopoulus. 1976. Economic of Development Empirical Investigations. Harper International Edition. Harper \& Row Publisher, New York and London.

Nuraini, I.G.S. Budisatria, dan A. Agus. 2014. Pengaruh tingkat penggunaan pakan penguat terhadap performa induk kambing Bligon di peternak rakyat. Buletin Peternakan 38 (1): 3441.

Paudel, K.P., N.R. Martin, G. Wehtje \& T. Grey. 2013. Economic Decision making Using Enterprise Budgeting andStatistical Analysis: An Illustration in Weed Control Practices in Peanut Production. Journal of Production Agriculture 11 (1): 48-52.

Pica-Ciamarra, U., L. Tasciotti, J. Otte, A. Zezza. 2015. Livestock in the household economy: crosscountryevidence from microeconomic data. Development Policy Review 33 (1): 61-81.

Stür, W., T.T. Khanh, A. Duncan. 2013. Transformation of smallholder beef cattle production in Vietnam. International Journal of Agricultural Sustainability 11 (4): 363-381. 
Verschelde, M., M. D'Haese, G. Rayp and E. Vandamme. 2013. Challenging Small-Scale Farming: A Non-Parametric Analysis of the (Inverse) Relationship between Farm Productivity and Farm Size in Burundi. Journal of Agricultural Economics 64 (2): 319-342.

Widiati, R. 2006. The integration of beef cattle farming system on the farm household in Merapi Volcanic Slope, Sleman Yogyakarta (The Application of Linear Programming Analysis Model Toward Sustainable Livestock Development). Proceeding of The 4th Inter-national Seminar on Tropical Animal Production. Faculty of Animal Science, Gadjah Mada University, Yogyakarta Indonesia. Pp. 536-541.

Widiati, R. 2012. Financial feasibilityof beef cattle breeding with various capital aids in rural area of Gunung Kidul District of Yogyakarta. Bulletin of Animal Science 36 (2): 1-7. 